\title{
Study of Human Resources Management and Performance Analysis in Foreign Enterprises
}

\author{
Jiaxuan Wang ${ }^{1, a}$, Tao Yue 2 , b \\ ${ }^{1,2}$ Qingdao Huanghai University, Qingdao, 266427 \\ ${ }^{a}$ email, ${ }^{b}$ email
}

Keywords: Human Resources, Enterprise Performance; Foreign Enterprise Process Capability

\begin{abstract}
In the era of knowledge economy, business environment has undergone dramatic changes, competition among enterprises has risen to technological competition and technological competition is more marked in high-level talent competition, human resource management in the enterprise competition and more important, so relationship between human resource management practices and Firm performance how, how to help companies gain a competitive advantage is increasingly becoming an important issue and other issues of human resource management research. On the basis of existing research results at home and abroad, with 62 foreign companies for the study, empirical analysis of the impact of human resource management practices on firm performance, and provide reference suggestions human resource management practices.
\end{abstract}

\section{Introduction}

Research on the relationship between human resource management practices and firm performance has been an important topic in the field of human resources management. With respect to overseas research, domestic research started late, rarely sub-industry research, even if only to traditional manufacturing class and business class services for the study, few high-tech industries involved in this particular industry. This paper enterprises in Jiangsu Province as the research object, using descriptive statistics analysis and structural equation, etc., from the empirical point of view to _ the impact of human resource management practices audit companies on corporate performance, rich human resources management practices and corporate performance Empirical studies for the development of the theory of human resource management practices provide empirical support, it has some theoretical significance. From a practical point of view, compared with Western countries, China's enterprises' awareness on human resources management still very weak, did not form a sound human resources management system. Many domestic enterprises still can not correctly understand the value and importance of human resource management human resources management, HR as a business merely auxiliary and support department underestimated the human resource management practices on firm performance IMPACT, and companies a similar problem exists. Unlike traditional business enterprises with the characteristics of investment in human resources in the process of enterprise development is particularly important, management of human resources is the driving force for enterprise development. However, domestic enterprises have realized the importance of human resource management, but still not the function of HR for accurate positioning, resulting in poorly designed remuneration, personnel incentives is not clear, imperfect performance evaluation and other issues, thus adversely affect business performance. Therefore, to explore a set of effective human resource management practices, help improve the company's human resources management system, to enhance corporate performance and competitive advantage has a very important practical significance.

\section{Human Resource Value Chain}

The research and development, value chain theory gradually expand to other areas of research. Therefore, many scholars began to value chain theory applied to human resources management, human resources management in order to further explore all value-added activities. Similar to the value chain, value chain, human resources (HR Value Chain) is also a value-added process, aimed 
primarily at the Human Resources Management practices to improve organizational performance in a series of activities related outputs thereof. In the value-added process, companies with good human resource management practice is based in turn improve employee performance, organizational performance, financial performance and market performance, and ultimately promote enhance corporate performance. Deyer \& Reeves (1995) the first of human resources value chain research in the study of organizational performance measurement method, they found that the four dimensions of organizational performance has a certain causal relations, human resource management practices through the causality have a certain impact on business performance. First, the role of human resource practices in employee output, then the output will affect organizational outcomes employee organization affected output after the financial role in output, followed by the financial outputs then act in the enterprise market output, and ultimately lead to business performance changes accordingly.

\section{Research Methods}

The study sample included 62 joint ventures and wholly foreign-owned manufacturing subsidiaries by author previous contacts and use / 0 snowball technique, and these companies made contact. This means acquiring business details when it is necessary [28] the sample of the vast majority of enterprises in Tianjin, the rest distributed in Beijing, Shanghai, Guangzhou and Shenzhen. there are 25 samples of parent companies in the United States, 37 of the parent company in Europe and Australia. If $80 \%$ of foreign investment as a joint controlling stake in the cut-off point [29], then 62 in 24 can be defined as a joint venture enterprise from the performance point of view, there is no clear distinction between joint ventures and wholly-owned subsidiary, the study will both as a whole research study using interview methods, the use of pre-designed questionnaire to respondents questions. questionnaire two points in the English version, and the use of back-translated the way the questionnaire were checked for expatriates interview in English questionnaires, interviews with Chinese management personnel employed in Chinese questionnaire. most of the respondents are corporate human resources or personnel department manager, in which 14 respondents (22.6\%) are expatriates in human resource management system, human resources management and integration strategy and corporate performance, etc., between expatriates and found no significant difference in the local respondents, therefore, they will be analyzed together.

Discussion. This variable is used to reflect the degree of use of a series of business / 0 high performance human resource management measures, referred to as HRM systems with reference to the literature The questionnaire design, the present study used questionnaires in the application of human resource management on corporate the degree of continuity of the use of scale without the use of a non-variable problem consists of the following 11 aspects: the recruitment of former staff positions to be recruited should possess the skills / qualifications / features ratio analysis; the new employees hired through a formal recruitment process. the average number of recruiting panel members; new employees in the first year the average training time (number of days); older employees receive training each year the average time (days); the ratio of the degree of work performance play a role in the promotion in post (using Likert level 5 scale); the proportion of at least a year to accept a formal performance evaluation of employees occupied; bonuses based on the average proportion of its total revenue of individual performance assessment issued each year; job analysis of the proportion of jobs; at least each year a staff attitude survey of proportion; the proportion of employees to share organizational information will be standardized answers to these questions as the average index of human resource management systems, human resources management system for numerical variables representing the composite variable. ?? coefficient of 0.58, which indicates consistency 11 areas not too good. However, the results obtained with similar studies in the United States similar to, taking into account the content covers a wide range of variables, this value is acceptable in addition, the literature the authors believe that the use of integrated human resource management system metrics can accommodate different business changes and differences in individual measures. (2) integration of human resource management and corporate strategy using the literature 3 on the question raised: enterprises in the integration of 
corporate strategy and human resources (or personnel) made a strategic effort to what extent human resources (or personnel) departments in the extent of the involvement of the corporate strategic planning process of human resources (or personnel Manager) sector is considered the extent to which agents of corporate governance change partners and staff of other departments? ?? coefficient of the composite variable is 0.82 , is satisfactory. the variable is referred to as the HRM strategy .

Dependent Variability. In this study, enterprise performance as the dependent variable Performance of Enterprises with Foreign Investment by four to reflect subjective evaluation: expected profit for the parent company and a subsidiary of overall performance satisfaction; compared with other foreign-invested enterprises in the same industry, subsidiaries results of operations and profitability if the parent so satisfied to answer questions because the 5-stage scale foreign-invested enterprises operating in China have different objectives (eg: to gain market share, understand the market, access to short-term profits, etc.). Therefore, relatively short-term financial performance of companies with different objectives, is not particularly meaningful. subjective measure of corporate performance helps managers according to business goals to evaluate the performance. Although this data may increase the emotional evaluation of subjective bias and error, but on the whole, it has more good than harm. In the past, similar studies have been such a precedent. in addition, previous studies have shown that the subjective and objective indicators of corporate performance indicators are highly correlated. the composite variable coefficient is 0.92.

Control Variables. Experience in foreign invested enterprises may affect human resource management practices and business performance have more experience in China's enterprises may have experienced a familiar and comfortable with China's specific learning environment, therefore, experience and corporate foreign-invested enterprises, the parent company of perhaps there should be a positive relationship between performance. based on this consideration, the life of the parent company in China to establish the first foreign-invested enterprises as a control variable. surveyed enterprises operating life should be performance-related, because business hours long business may have adapted to China's environment, rather than the success of foreign-invested enterprises may have disappeared. Therefore, the business of operating life is as the second control variables in this study. The third control variables, firm size, with staff the number of reactions. Finally, the country of foreign-invested enterprises is the parent company as the fourth control variable. studies have shown that, in human resource management practices overseas, the United States is different from the multinational companies in other countries for joint ventures several studies have shown that US multinationals are more likely than the European multinational human resources management measures transplanted directly to the home country of their joint ventures in China. Therefore, this study will be the home country of foreign invested enterprises as a control variable, We tried to examine the impact of this factor on the human resource management and enterprise performance.

Table 1 Regression model with standard regression coefficient 1 Business Performance

\begin{tabular}{|c|c|c|c|c|c|c|c|c|}
\hline Argument & model1 & model2 & model3 & model4 & model5 & model6 & model7 & model8 \\
\hline $\begin{array}{c}\text { Multinational } \\
\text { experience }\end{array}$ & 0.16 & 0.1 & 0.14 & 014 & & & & \\
\hline Business life & & & & & & & & \\
\hline Company size & 0.06 & 0.14 & 0.1 & 0.11 & 0.1 & 0.1 & 0.05 & 0.06 \\
\hline Home Country & 0.24 & 0.07 & 0.05 & -0.01 & 0.2 & 0.03 & & -0.05 \\
\hline HRM system & & & 0.48 & & 0.27 & & 0.47 & \\
\hline $\begin{array}{c}\text { HRM } \\
\text { Integration } \\
\text { Strategy }\end{array}$ & & & 0.57 & & 0.45 & & 0.57 & 0.45 \\
\hline R2 & 0.047 & 0.244 & & & & & & \\
\hline Adjusted R2 & 0.0932 & 0.293 & 0.380 & 0.427 & 0.121 & 0.317 & 0.408 & 0.452 \\
\hline F statistic & 1.993 & 5.918 & 8.729 & 8.358 & 2.650 & 6.505 & 9.815 & 9.232 \\
\hline The change R2 & & & 0.2 & 0.286 & 0.334 & & 0.196 & \\
\hline $\begin{array}{c}\text { F statistic R2 } \\
\text { Changes }\end{array}$ & & 16.13 & 26.33 & 17.04 & & 16.37 & 27.66 & 16.92 \\
\hline Sample n & 62 & 62 & 62 & 62 & 62 & 62 & 62 & 62 \\
\hline
\end{tabular}

Regression includes only control variables does not make sense, because there is a control 
variable is statistically significant (Table 2 Model 1 and 5). The human resource management system was added after the regression equation model occurs a significant change, adjustment after R2 0.244 and 0.269 (model 2 and 6). human resource management system is the only enterprise performance has a significant determining factor $(P<0.001)$. the use of human resources management and strategic integration instead of human resource management systems. model 3 regression analysis and 7 results than the previous showed significantly higher statistics on, R2 respectively 0.336 and 0.366 . in other words, the integration of the overall model and human resource management and strategy has been highly statistically significant in the model 7, business life has also become an important predictor of firm performance $(\mathrm{P}<0.05)$. Finally, the control variable, human resources management system and two models including human resource management and strategic integration of the analysis, the regression is significant the (adjusted R2 for the 01376 and 01403), human resources and integration management strategy is on the business performance of the biggest factors, human resource management systems with enterprise performance positively correlated $(\mathrm{P}<0.05)$, business life is also the same corporate performance positively correlated $(\mathrm{P}<0.05)$. in summary, the present study results to two assumptions herein provide strong support. Therefore, within the scope of the sample surveyed enterprises with foreign investment, human resource management systems and human resources management and integration strategy are on firm performance have a positive effect. in addition, business life have a positive impact on business performance.

\section{Conclusion}

While the human resource management system and human resources management and the degree of integration strategies on business performance had a significant effect, however, the impact is different. We find that, on investigation of the enterprise, the management level human resources and strategic integration of corporate performance. this is different from the impact of bigger foreign similar study concluded reason for this result might be: first, China's fast-changing competitive environment, companies must make frequent changes in competitive strategy, in order to remain competitive, companies must be adjusted accordingly human resource management practices; second, because the foreign-invested enterprises to undergo a process of learning and adaptation, therefore, the integration of human resource management and organizational strategy is necessary, human resources management department plays an important role in corporate strategy development process ; third, compared with Western countries, some of the human resource management practices of high performers may not work effectively in China, it is necessary for all aspects of human resource management practices detailed analysis.

\section{References}

[1] Arthur,J.B. The link between business strategy and industrial relations systems in American steel minimills [J]. Industrial and Labor Relations Review,1992,3(45):488-506.

[2] Becker, B.E. Huselid M.A. Crisis and opportunity: the two faces of human resource management in the 1990s and htyonar [J]. Corporate effectiveness and human resource practice,1996(3):45-52,

[3] Becker,B E. Barry Gerhart. The impact of human resource management onorganizational performance; Progress and prospects [J]. The Academy of ManagementJournal ,1996A09): $779-801$.

[4] Bemardin, H. J.,Kane, J. S.,Ross, S., Spina,J.D. \& Johnson,D.L. Performance appraisal design, development and implementation [M]. In: Ferris,GR.,1995.

[5] Bredrap, H. Performance Evaluation [M]. In Rolstadas,A. (ed.) Performance Management: A Business Process Benchmarking Approach (Chapman \& Hall, London, United Kingdom), 1995:191-198. 